\title{
BREEDING OF JERUSALEM ARTICHOKE WITH THE DESIRED TRAITS FOR DIFFERENT DIRECTIONS OF USE: RETROSPECTIVE, APPROACHES, AND PROSPECTS
}

\author{
(review)
}

\section{BRETON1, S.D. KIRU², A. BERVILLÉ3 ${ }^{3}$, N.Yu. ANUSHKEVICH ${ }^{2}$}

\author{
${ }^{1}$ Institut des Sciences de l'Evolution de Montpellier (ISE-M), UMR CNRS 5554, Place E. Bataillon, cc63, BBt 22, 1er \\ étage, F-34095 Montpellier Cedex 5, France, e-mail catherine.breton02@univ-montp2.fr (corresponding author); \\ ${ }^{2}$ Federal Research Center the N.I. Vavilov All-Russian Institute of Plant Genetic Resources, Federal Agency of \\ Scientific Organizations, 42-44, ul. Bol’shaya Morskaya, St. Petersburg, 190000 Russia, e-mail s.kiru@vir.nw.ru, \\ topinam2012@yandex.ru; \\ ${ }_{3}^{3}$ Institut national de la recherche agronomique (INRA), UMR DIAPC 1097, 2 place Viala, BBt 33, F-34060, \\ Montpellier Cedex 2, France, e-mail andre.jp.berville@orange.fr \\ ORCID: \\ Breton C. orcid.org/0000-0002-3389-1861 \\ Kiru S.D. orcid.org/0000-0002-8648-3837 \\ Bervillé A. orcid.org/0000-0002-7426-2287 \\ Anushkevich N.Yu. orcid.org/0000-0001-6125-6139
}

The authors declare no conflict of interests Received June 11, 2017

\section{Abstract}

In the last decade, a new direction has been widely developed for industrial and food use of Jerusalem artichoke (Helianthus tuberosus L.). At the same time significantly expanded the cultivated areas of this crop, especially in Asian countries. Relevant extension studies therefore becomes focused on breeding of new varieties, including those with high content of certain biochemical components in tubers or leaves and stems. The future of J. artichoke as energy source for biofuels, as well as a source of fiber, sugar substitute for people, who require insulin is very promising. Despite the presence of a large number of varieties (more than 300) of $\mathrm{J}$. artichoke in different countries, its genetic diversity is not so wide (P.P. Wangsomnuk et al., 2011; R. Puttha et al., 2013), because all breeding varieties are based on intraspecific hybridization, or as result of selection of seedlings from self-pollination. In addition, due to the very low self-fertility, the breeding of $\mathbf{J}$. artichoke and its generative reproduction has yet little success. The experience on multi-year studies of J. artichoke diversity and breeding work in many countries shows, that the effect of highdirected breeding on desired traits can be achieved only through inter-specific hybridization. The crossing J. artichoke with sunflower, allows transmitting at new generation the characters and properties of the initial forms and improved through heterosis (L. Natali et al., 1998; C. Breton et al., 2010). Thus, we can say with great certainty about reality of $\mathbf{J}$. artichoke breeding to achieve the desired traits using inter-specific hybridization. The inter-specific hybridization of artichoke $\mathbf{J}$. artichoke with sunflower (Helianthus annuus L.) can be successfully use as a breeding method for creation of varieties with the desired traits for specific uses. Given the current demand for different directions of use products from $\mathbf{J}$. artichoke, it is likely that the breeding of $\mathbf{J}$. artichoke will be focused on creation of special varieties - for food, for medicinal purposes, for processing in the inulin, purposes of animal feeding, for the production of bioenergy, technical and environmental goals etc. (M. Baldini et al., 2004; G.J. Seiler et al., 2004; R. Puttha et al., 2012; S. Favale et al., 2014). We can say with confidence that there are enough initial material for all areas of breeding. For these, it is necessary to extend the researches to find the possibilities of using the existing gene pool of artichoke in many gene banks. Today, there are a different of modern methods for this, including molecular genetics. One has to stress for breeding J. artichoke the importance of molecular genetics technologies towards the existing gene pool of artichoke in many gene banks.

Keywords: Jerusalem artichoke, sunflower, breeding, hybridization, selection, target traits, food and forage use, raw for use, inulin production, bioethanol production

To breed varieties for a new use, it requires to start on a wide genetic basis to ensure enough diversity in the future crop. In the past, several crops have been transformed from a specific use to undergo new uses. Several examples could be developed and among them are the crops, devoted to 
industrial uses such as sunflower (Helianthus annuus L.), cotton, safflower, fiber crops, linseed to make them an oil crop for food and recently extant to bio-fuel. The second example is the root beet transformed into sugar beet in France at the beginning of the eighteen century to provide sugar because of the blockade set up by England to cut France from its colonies to import sugar from sugar cane. Louis de Vilmorin (1850) has initiated sugar beet breeding and the main issue of the research has been to harvest sugar beet plants separately, and not in mixture enabling selection of individuals with with improved sugar quantity. Root beet was devoted to feed livestock, it contains by $10 \%$ sucrose and lower than in table beet, but only Root beet was chosen because it was white devoid of anthocyanins that makes white sugar, while because table beets that may content more sugar are frequently colored, they were carefully not used to get sugar.

Sunflower story may shed light on this process and may give back what we have to do on $\mathbf{J}$. artichoke (Helianthus tuberosus L.) before starting a biotechnological platform to industrial production of inulin. Confectionery sunflower has been transformed into an oil crop between 1860 to 1920 by Russian peasant selection to give fat, because confectionery sunflower was not on the list of forbidden plants to eat during the Orthodox Lent. During the Lent period confectionery sunflower provided fats. Moreover, the seeds were commonly eaten after baking and salted. Thus, scientists from the VNIIMK (All-Union Research Institute of Oil Crops, former USSR) decided by the 1930's to screen through mass selection, populations thriving in plenty of gardens for those with the most oil content. Each center had constituted one population by mixing all the sources. The history of oil sunflower remains unclear because most of the geneticists involved did not agree Lysenko theories and have disappeared in jails. These tasks done in four main research centers have released all oil Russian sunflower populations which are now designed as old Russian populations (ORP).

For researchers not specialized in plant breeding it may appear superfluous to spend time on this reflexion because the diversity of $J$. artichoke is widely kept in several worldwide institutes [1-5] and hundreds of clones appeared sufficient to carry out breeding programs. However, there is no genetic diversity in a $\mathbf{J}$. artichoke clone and thus the diversity is only between clones. The number of clones to handle for breeding $\mathrm{J}$. artichoke should be therefore very important. The diversity can come only from new J. artichoke varieties screened in the progenies of crosses between $\mathbf{J}$. artichoke clones. Wild and feral J. artichoke thrive as clones, but they may also come from seeds [6], that was rarely observed from feral J. artichoke [7]. Seeds of J. artichoke are tiny, they are as small as for wild sunflower, with the same troubles to induce germination because of their dormancy, due to integuments. Thus it is required to make an incision onto the integument and to bath seeds in Ethrel or GA3 to enable fast germination. The novel protocol for seed germination improvement of $\mathbf{J}$. artichoke has been published by P. Wangsomnuk [8] which demonstrated that the exogenous supplementation of growth regulators and temperature improved germination of dormant seeds under in vitro and in vivo conditions.

The length of the vegetative period from a tuber put in soil to blossoming is determined by the sum of temperature of each day. One clone has a threshold genetically determined and when the sum of temperature from each day, and as long as the threshold is not reached the plant cannot blossom. For a given threshold the time length to get blossoming depend on the average sum of temperature and as high the temperature as short the delay to blossoming.

Today Jerusalem artichoke, due to its richness of biochemical and mineral components, is rapidly growing demand for its multilateral use [9-11]. 
As $\mathbf{J}$. artichoke was commonly used for animal feed the concentration of minerals has been studied [12-14]. Also, in the last two decades, interest in Jerusalem artichoke has resumed in many countries, as a plant from which cheaper alcohol can be obtained [15-17], both from tubers, as well as from above-ground biomass $[18,19]$. The economic benefits of the production of Jerusalem artichoke alcohol have been proven in many countries [19-22]. Accordingly, for this direction, no doubt, we need varieties of Jerusalem artichoke with the highest content of sugars. The demand for raw materials from Jerusalem artichoke for biofuel production is noticeably increasing in various countries [23].

However, for future uses, the main storage compound in $\mathrm{J}$. artichoke is inulin that is synthesized in leaves by photosynthesis and accumulates in the vacuole of each cell. Starch is poorly present in leaves, thus, the inulin induces osmotic pressure depending on its polymerization degree [24]. Among J. artichoke clones the trait "inulin content" displays a wide range of variation and "inulin yield at harvest" is the trait to improve for a biotechnological platform. However, not all environmental factors that influence on inulin content at harvest time are known yet, but such influence factors were confirm manifold [25$29]$, including irrigation [13, 30,] as well as the harvesting dates, methods and conditions for storing tubers [27, 31, 32].

The range of variation between different clones is due to genetic differences in their potential. Thus, the targeted screening of breeding material should release new varieties with regular higher inulin content, which justifies the cost of the breeding program [33].

The choice of parents to obtain new progenies remains random because we have no knowledge on the complementary effects between J. artichoke varieties to release new varieties with improved inulin content at harvest time. We have to define strategies to help breeders to make the best crosses by choosing the adequate parents in order to succeed in the breeding program. Sunflower has been improved partly by crosses with $J$. artichoke such as $q$ sunflower $\times \hat{\delta}$. artichoke because in this direction the progenies provide most annual plants without tubers. To transfer valuable genes from $\mathbf{J}$. artichoke to sunflower, crosses have to

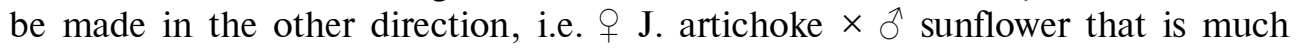
more difficult to carry out, but ensure most plants with tubers [34].

Another difficult feature to breed J. artichoke is that it is hexaploid carrying 3 times more chromosomes than sunflower [34]. It has been shown that $\mathbf{J}$. artichoke is probably auto-polyploid carrying 3 different elementary genomes named $\mathrm{H}, \mathrm{C}$ and $\mathrm{P}$ [35], as other polyploid species, H. tuberosus displays any regular meiosis et is partially female fertile. Moreover, J. artichoke displays a strong self-incompatibility system that prevents a plant to produce seeds after self-pollination. Because S-alleles in J. artichoke have not been identified success or failure of crosses between clones cannot be predicted and several crosses have to be done to ensure some will succeed [34].

Although it was a long way, the two successes for transformation to adapt crops to be used for other purposes revealed the difficulties, which the breeders will face in J. artichoke adaptation to new uses. Thus, it is important to explain which difficulties may be encountered with J. artichoke, for higher inulin content at harvest.

Diversity: phenotype and genotype. The Jerusalem artichoke originated in the east of the North America at latitude (between $45^{\circ}$ North to $27^{\circ}$ South). Depending on the latitude origin of the clone once transferred to Europe, in Montpellier as example (latitude $42^{\circ}$ North) plants that had origin in the North start the flowering earlier than those from South. Clones flowering between the end of June to October, and clones that have not flowered in Octo- 
ber indicate the presence of phenotypic diversity. The date of flowering is important and has to be as late as possible, that will avoid plants to loose energy for flowering [36]. Wild forms of J. artichoke have tiny tubers with more or less cylindrical shape. Seeds from wild J. artichoke display difficulties to germinate because of integument dormancy. Seeds from cultivated J. artichoke display the same difficulties to germinate and have to be treated as wild seeds. The tuber shape and size displayed by one $\mathbf{J}$. artichoke clone depends both on the latitude and the average temperature of days during the growing season (between planting to harvest) [28].

In the former USSR the majority of $\mathrm{J}$. artichoke varieties and hybrids were produced by a clone selection method from local populations and forms of foreign origin and by selection from the achene - grown seedlings from free pollination of cultivated varieties. In 1966-1972 at VIR's Maycop experimental station an inter-varietal hybridization was carried out, the tests showing its favourable prospects for J. artichoke breeding [37]. Among the seedlings grown, a large diversity of hybrid forms was noted, comprising positive characters of initial parental forms and suitable to be used for crop production as well. Ethanol production has been a goal

For the first time, the breeding work on J. artichoke began in USSR by the 1934-1936 years, when several seedlings were obtained from inter-varietal crosses, the greatest success achieved [38-40]. Their breeding method was based on the inter-varietal hybridization followed by selection of seedlings. The scheme of the selection process included 5 stages: 1) the obtaining seeds from open pollination and artificial hybridization; 2) growing seedlings and evaluation in the first year of life; 3) comparison of the vegetative progeny of seedlings in the second year of life; 4) a preliminary test of selected clones; and 5) other types of tests. N. Schibrya [38] in the one of his works noted about importance to attract attention to necessity of crosses certain parental forms, bearing the desirable traits. And the most interesting $F_{1}$ plants then easily can be fixed in vegetative propagation. The experience in VIR breeding works, including experiments under the leadership of the breeder Nicolay Pas'ko [40], shows that some Caucasian and French forms (Var), e.g. Blanc precoce, as well as 3 wild species, $H$. macrophyllus Willd, H. subcanescens (Grau) Wats and H. rigidus (Cass) Desf., should be involved as donors. Since J. artichoke, as cross pollinator, is heterozygous, than the breeder can always expect to obtain from the use self-pollination of plants segregation to recessive forms that can be practically valuable.

An evaluation of a wide diversity of $J$. artichoke 315 varieties from 24 countries, collected during 80 years in N. Vavilov Institute (VIR) collection [3], showed that some varieties have the same high seed productivity as well as sunflower and not all forms have a low fertility. The analysis of studies in intervarietal crosses showed that the formation of germinal seed of $\mathbf{J}$. artichoke cultivars in a pairwise crossing varies from 0 to $98 \%$ [40]. The crossability in some combinations reaches $75-98 \%$, each pollinated inflorescence gives 20-30 seeds, but the average statistical accounting the achenes germ forming reaches no more than $11 \%$. Most important factors are the place and time, air temperature and humidity. For example, in foothills of the Caucasus Mountains, the best time for crossing is the second decade of July until the first decade of September [37].

Presently, the diversity in J. artichoke crop is represented by about 300 clones and it may have redundancies between collections based on the same names of a clone or deformation by translation of names. Even though the phenotypic diversity is apparently huge as shown in results of some studies [40, 41], the genotypic diversity is insufficient to start a breeding program on this basis. Studies published by R. Puttha et al. [26] which have studied about four tens of 
clones, showed that the molecular diversity - supposed to be neutral - is low between clones. In contrast, each $\mathrm{J}$. artichoke seed will generate a putative clone, and thus the phenotypic and molecular diversity of wild J. artichoke propagated by seeds is much more than the diversity of clones, but of course, wild $\mathbf{J}$. artichoke have not been screened for the quality of their tubers. In the same way seeds from $\mathbf{J}$. artichoke clones will lead to plants with a range of diversity on tubers color and shape. Seeds are obtained on to the female plants by crossing with an unknown male unless the cross has been controlled and the male was identified. In INRA J. artichoke collections, we have harvested thousands of seeds $(200 \mathrm{~g})$ that were conserved in a cold room as genetic resources by institute. Noticeable is that on a $\mathbf{J}$. artichoke head a few of flowers give seeds, and we found broadly 5 seeds per head whereas the number of flowers is by 60 . We hypothesized that this is due to the self-incompatibility system in J. artichoke and also due to its polyploid structure. Several authors have studied meiosis in $\mathbf{J}$. artichoke and they did not reveal abnormalities such as laggard segregation [42]. However, if most pollen grains are rejected, this cannot be due to the self-incompatibility system only, and we should hypothesize that pollen grains do not carry the adequate chromosome number.

The important point to increase seed productivity is the choice of varieties-pollinators. For example, var. Vengersky at crossing with var. Tambovsky krasnyi gives the highest percentage (98\%) of seed setting. Of course, the germ forming depends from the fertility of maternal form. According to our observations, at VIR's Maycop experimental station the best parent varieties, providing the highest percentage of seed setting are Vengersky, Tambovsky krasnyi, Gorno-Altaiskyi. Moreover, in order to predict the level of achene germ forming and plan the work for their obtaining, when are going to select the parental pairs for crossing, there is necessary to know their combining ability for seed productivity. Also in breeding work, when doing the selection of varieties for the crosspollination, it is very important to know the extent of pollen fertility, because it increases the seed productivity of maternal forms of $J$. artichoke. The increase in a percentage of achene germ forming depends on involved pollinator varieties with high pollen fertility. N. Pas'ko [40] proved that the larger the pollen, the higher the fertility is.

The analysis of inheritance of desired traits in the progeny of intervarietal crosses shows that there are different degrees of trait dominance and compulsory segregation of characters. Therefore, the most likely way for success is selection of seedlings in the first generation with further testing in second vegetative reproduction

The variability on inulin content at harvest time. The Jerusalem artichoke varieties are characterized by a wide variability in inulin and sugar content [23-26, 32, 33] and elements productivity, which depend on environmental conditions significantly [43-46]. As for all traits that follow quantitative variation, inulin content at harvest should be evaluated for a series of putative parents of future $\mathbf{J}$. artichoke clones by crossing them following the diallel design as male and female. The method provides information on the value of each clone in the assay as male and female parents. Moreover, the method allows further choosing parental clones with complementary parameters favorable to the higher content in inulin at harvest time. Obviously, the clones and a few of progenies can be evaluated simultaneously for other traits such as disease and abiotic stress tolerance. Clearly, this experiment is heavy but without this information obtained from each clone all mates will be made in blind and successes may be low. In addition, in order to assess the potential of selected seedlings for the manifestation of characteristics, the evaluation of the selected clones of seed- 
lings should be carried out comprehensively, in different ecological and geographical conditions, as well as in various backgrounds - including with the irrigated method of cultivation. The results of the applied research of the last decades on Jerusalem artichoke show the influence of various factors both on the productivity of Jerusalem artichoke and on the biochemical content of tubers and aboveground biomass [23, 25, 47-50].

Variability on inulin content in tubers. Plenty of studies have released variation for inulin content at harvest in $\mathbf{J}$. artichoke [14], but none has release which clones could be the best parents to improve the trait inulin content at harvest. The yield in inulin levels out at $19 \%$ of the tuber raw material. The upper theoretical limit is probably around $22-25 \%$ as judged by other crops (chicory) that produce inulin in roots.

Variability of inulin in leaves and stems. Most J. artichoke growers harvest only tubers and leave the stems to dry and if harvested it is for fire wood. Stems are rich in cellulose and could enhance profits from the crop. They also contain inulin that could be extracted by water treatment and thus the yield of the crop is indeed enhanced. The same design described previously could serve to estimate the potential of each $\mathbf{J}$. artichoke clone as a parent one.

A guide to mate Jerusalem artichoke clones. To mate two J. artichoke clones requires to envelope with a paper bag one head of the plant, chosen as female, to prevent unwanted pollination and when the stigmata rose above the tubular hermaphrodite flowers, the pollen from another plant has to be spread with a small brush onto the stigma surface. The pollen is harvested onto the one or several heads from the male plant that has enveloped in a paper bag. The pollen is introduced into the paper bag of the female heads. Ten to fifteen heads of the female have to be treated for one cross to ensure to have enough seeds. Seeds are mature one month and half later and as birds are very fond of them, they have to be protected under the bag until harvest.

Another method consist in leaving all heads free pollinated (at the condition that none sunflower plants may blossom in the area). The J. artichoke clones, which have been evaluated for the inulin production, could be mixed in a plot for seed production. Bees are able to transport pollen up to $5 \mathrm{~km}$ from the source. In general, around Montpellier sunflower is not cropped in the fall and protection of heads is useless. Without bag protection, the yield in seeds is higher, i.e. several grams can be obtained and the diversity in the progenies is ensured. Seeds could be harvested on the clones of female plants that display the higher ability for inulin content. To obtain seed germination is a challenge, one has to break dormancy, both due to integuments and to hormone balance. Several methods for seed treatments have been published [51, 52] by scarification and/or hormonal treatments. Once the root has come through the integument the seedling is immediately transferred in a pot with sandy soil without too much moisture to avoid mold and rotting diseases [53]. Each plant is single, and all are different from each other and thus before evaluation each plant able to give tubers has to be retained. The evaluation plots should consist in a field plots with repeats of tubers and random distribution of them. The field plot is costly and has to be repeated each year for new plants. The bottleneck for getting enough genetic diversity is at this level and thus the step cannot be shifted.

If progenies from hybridization between $J$. artichoke and sunflower are looking for, in Montpellier we planted sunflower rows (different hybrids) besides the J. artichoke clones. Once seeds have been harvested and cleaned, they are separated based on the size (the upper size will be enriched in hybrid seeds).

Field experiments. Pre-screening of clones able to produce tubers in the local field conditions is not sufficient for an acceptable agronomic behavior of 
clones and requires verification in usual seeding. Conventional agronomic plots should be carried out for their evaluation. Each evaluator has different evaluation criteria because of the agronomic environment and the aim of the production he (her) works with. The screening for hybrids between J. artichoke $(2 n=102)$ and sunflower $(2 n=34)$ requires cytological controls such as chromosome counting (the hybrids should display 68 instead of 102 chromosomes). Such plants are called Topinsol. The diversity of Topinsol forms is scarce because crosses have not been made with breeding aims. Their potential is practically unknown, but in J. artichoke collections, Topinsols are detected only by cytological analyses that means they probably yield tubers as $\mathbf{J}$. artichoke clones.

Use inter-specific hybridization. The Russian breeders were the first in the world who created the inter-specific hybrids between J. artichoke and sunflower in 1935 [37-39]. It was a new artificial species tuber-bearing crop. Genetically, J. artichoke and sunflower are members of polyploid series. J artichoke is hexaploid $(2 n=102)$, sunflower is diploid $(2 n=34)$. In the somatic cells of $J$. artichoke and sunflower hybrids there were 68 chromosomes, which is consistent with the theoretical assumption of 51 chromosome from J. artichoke and 17 chromosomes from sunflower [54-56].

Since the most of $\mathbf{J}$. artichoke varieties involved in breeding have a late and middle maturity, to accelerate the flowering it is possible to use a method of reducing the day length providing the creation of seeds to be held in a more favorable time for this. For this, it needs to tie the leaves from the stalk to reduce their photosynthesis to $10 \mathrm{~h}$ of daylight. This method allows accelerated flowering from 2 to 60 days and a successful crossing with sunflowers. At VIR's Maykop experimental station in 1966-1980, more than 25 varieties of artichoke, 3 of Helianthus wild tuberous species and 13 varieties of sunflower $H$. annuus L. were involved in crossing and has been cultivated over 10,000 seedlings of interspecific hybrids $\left(F_{1}\right)$. The level of achene germ forming from crossing J. artichoke with sunflower is small - 0.1-4.5 \% [57-59]. In VlR, Dr. N. Pas'ko [37, 40] assessed $\mathbf{J}$. artichoke varieties on ability as pollinators and he singled out the most fertile var. Patat Vilmorin, Maykopsky 33-650, Vengersky, which provide $42-46 \%$ seed germ forming. The efficiency of seed productivity of J. artichoke depends on the fertility of parent forms pollinators of sunflowers. More fertile forms of $\mathbf{J}$. artichoke at their pollination by the same varieties of sunflower annually have a tendency to retain their best cross ability. Conversely, the varieties with low fertility produce weak achenes germ forming [40, 60]. Analysis of inheritance degree of traits shows that the first generation of $F_{1}$ hybrids between $\mathbf{J}$. artichoke and sunflower thanks to heterozygosity present a wide diversity of forms. The analysis of traits of hybrid plants shows that their inheritance has an intermediate character or character of one of the parental forms. So, the height and thickness of stem, and leaf number are inherited mainly from the expression of heterosis [60]. The leaves of most hybrids become larger than that of $\mathrm{J}$. artichoke.

The tuber-creation of inter-specific hybrids in $\mathrm{F}_{1}$ appears as a dominant trait, and therefore almost all progenies (94-98\%) create the tubers. Also it was found that the obtained hybrid plants on the most morphological traits tubers retain maternal type, but at the same time increases the mass of tubers per plant, so the average weight of a tuber. In some combinations has created the plants with better tuber shape than the parental forms. Furthermore, it is important to note that the biochemical analysis indicates on increased sugar content in tubers of hybrid plants. The long-term evaluation has shown that the resulting heterosis effect persists in further propagation by tubers. For example at Maikop experimental station of VIR during many years inter-specific hybridization in 1984 was 
created var. Vostorg (Delight, in Russian) (3M-1-156), which was obtained by crossing of French var. Commun (high yield of tops of plants and high sugar content in it) with sunflower var. Gigant 549 (silage type). As a result, this hybrid has a yield of tops reaches up to 90 tons per hectare, with average of plant height up to 3.8 meters, and tuber yield 32 tons/ ha. The sugar content in the stems and leaves reached 16-18\% [37, 60]. Even greater success was achieved with the creation at VIRs experimental station in 1986 of inter-specific hybrid, which later became a famous whole country variety Novost' VIR (News of VIR, in Russian). The data of this class exceeded all previously created inter-specific hybrids. All the main agronomic and biochemical properties: yields of tops at experimental fields up to 100 tons per hectare and sugar content in them was $16 \%$, while at the same time, the tuber yield reached 60 tons per hectare, when the sugar content in the tubers was $18 \%$ and inulin was $14 \%$.

The future of $\mathbf{J}$. artichoke as energy source for bio-fuel as well as source of fibers and as sugar substitute for people, lacking of insulin is promising. However, because $\mathbf{J}$. artichoke has never been improved for these uses as its genetic basis is narrow and cultivars are clones, we suggested to improve J. artichoke for inulin content before looking for new varieties. This strategy has been found efficient to change confectionery sunflower in oil sunflower and to modify root beet in sugar beet.

Thus, it is safe to approve the reality of selective breeding to achieve a desired trait using inter-specific hybridization. Inter-specific hybridization of $\mathbf{J}$. artichoke (Helianthus tuberosus L.) with sunflower (Helianthus annuus L.) may be successfully used as a method of breeding directed to the improvement of the $\mathbf{J}$. artichoke plant and creating Topinsol comprising characters and properties of initial forms with the expression of heterosis. Given the current demand for different directions of using products from $\mathbf{J}$. artichoke, it is likely that the breeding of $\mathrm{J}$. artichoke is aimed at the creation of special varieties - for food, for medicinal, for processing, for inulin, for bioenergy, for feeding purposes etc. And we can say with confidence that there is sufficient initial material for all directions of breeding, the only need is to expand research in finding the possibilities of using the existing gene pool of Jerusalem artichoke in many gene banks. Today there are different modern methods for it, including molecular genetics.

\section{REFEREN C ES}

1. Serieys H., Souyris I., Gil A., Poinso B., Bervillé A. Diversity of Jerusalem artichoke clones (Helianthus tuberosus L.) from the INRA-Montpellier. Genetic Resources and Crop Evolution, 2010, 8: 1207-1215.

2. D i e d e ri chs e n A. Phenotypic diversity of Jerusalem artichoke (Helianthus tuberosus L.) germplasm preserved by the Canadian Genebank. Helia, 2010, 33(53): 1-16 (doi: 10.2298/HEL1053001D).

3. Kiru S., Nas e nko I. Use of genetic resources from Jerusalem artichoke collection of N. Vavilov institute in breeding for bioenergy and health security. Agronomy Research, 2010, 8: 625-632.

4. Wangsomnuk P.P., Khampa S., Wangsomnuk P., Jogloy S., Mornkham T, Ruttawat B., Pat a nothai A., Fu Y.B. Genetic diversity of worldwide Jerusalem artichoke (Helianthus tuberosus) germplasm as revealed by RAPD markers. Genetics and Molecular Research, 2011, 10(4): 4012-4025 (doi: 10.4238/2011.December.12.4).

5. W a ng som nuk P.P., Kha mpa S., Jogloy S., S rivong T., Pat a nothai A., $\mathrm{Fu}$ Y.-B. Assessing genetic structure and relatedness of Jerusalem artichoke (Helianthus tuberosus L.) germplasm with RAPD, ISSR and SRAP markers. American Journal of Plant Sciences, 2011, 2: 753-764 (doi: 10.4236/ajps.2011.26090).

6. At lagi ć J. Pollen fertility in some Helianthus L. species and their $\mathrm{F}_{1}$ hybrids with the cultivated sunflower. Helia, 1990, 13: 47-54.

7. Faure N., Serieys H., Bervillé A. Estimation of the risk of gene flow from cultivated sunflower to volunteer and wild Helianthus species in Europe. Agricultures \& Environment, 2002, 89: 183-190. 
8. Wangsomnuk P.P., Puangsomlee_P., Khampa_K., Jogloy_S. Exogenous supplementation of growth regulators and temperature improves germination of dormant Jerusalem artichoke (Helianthus tuberosus L.) seeds under in vitro and in vivo conditions. Journal of Applied Biological Sciences, 2015, 9(2): 23-30.

9. Eldridge S., Slaski J.J., Quandt J. Vidmar J.J. Jerusalem artichoke as a multipurpose srop. Proc. Annual Meeting of the Canadian Society of Agronomy (abstracts). Edmonton, Alberta, 2005 July. Available http://agronomycanada.com/download/meetings/past_meetings/2005\%20CSA\%20Annual\%20Meeting\%20Abstracts.pdf. No date.

10. Nemeth G., Izsaki Z. Macro- and micro-element content and uptake of Jerusalem artichoke (Helianthus tuberosus L.). Cereal Research Communications, 2006, 34: 597-600.

11. Favale S., Ciolfi G., Moretti S. Optimization of bioethanol production from Jerusalem artichoke powder and fresh tubers. Global Advanced Research Journal of Microbiology, 2014, 3(5): 72-77.

12. Terzi S., Atlagi J. Nitrogen and sugar content variability in tubers of Jerusalem artichoke (Helianthus tuberosus). Genetika, 2009, 41: 289-295 (doi: 10.2298/GENSR0903289T).

13. Geng-Mao Z., Liu Z.-P., Ming-Da C., Shi-Wei G. Soil properties and yield of Jerusalem artichoke (Helianthus tuberosus L.) with seawater irrigation in North China plain. Pedosphere, 2008, 18: 195-202 (doi: 10.1016/S1002-0160(08)60007-7).

14. Kays S.J., Nottingham S.F. Biology and chemistry of Jerusalem artichoke (Helianthus tuberosus L.). CRS Press, Boca Raton, Florida, 2008.

15. Curt M.D., Aguado P.I., Sanz M., Sanches G., Fernandes J. On the use of stalks of Helianthus tuberosus L. for the bio-ethanol production. Proc. Int. Conf. on Industrial Crops and Rural Development (abstracts). Mursia, Spain, 2005. Available http://www.aaic.org/past-meetingprogram-and-abstracts.html. No date.

16. Thanonkeo P., Thanonkeo S., Charoensuk K., Yamada M. Ethanol production from Jerusalem artichoke (Helianthus tuberosusL.) by Zymomonas mobilis TISTR548. African Journal of Biotechnology, 2011, 10(52): 10691-10697 (doi: 10.5897/AJB11.1680).

17. Park J.M., Ki m C.H. Ethanol production using whole plant biomass of Jerusalem artichoke by Kluyveromyces maxianus CBS1555. Appl. Biochem. Biotechnol., 2013, 169: 1531-1545 (doi: 10.1007/s12010-013-0094-5).

18. Ge X.Y., Zhang W.G. A shortcut to the production of high ethanol concentration from Jerusalem artichoke tubers. Food Technology and Biotechnology, 2005, 43: 241-246.

19. Szambelan K., Nowak J., Jele n H. The composition of Jerusalem artichoke (Helianthus tuberosusL.) spirits obtained from fermentation with bacteria and yeasts. Engineering in Life Sciences, 2005, 5: 68-71 (doi: 10.1002/elsc.200400052).

20. Hill J., Nelson E., Tilman D., Polasky S., Tiffany D. Environmental, economic and energetic costs and benefits of biodiesel and ethanol biofuels. PNAS USA, 2006, 103: 1120611210 (doi: 10.1073/pnas.0604600103).

21. Stolzenburg K. Topinambur (Helianthus tuberosus L.) Rohstoff fur die Ethanolgewwinung. Forchheim, 2006.

22. Izdebski W. Jerusalem artichoke - potential and possibilities of use in power industry. TEKA Kom. Mot. Energ. Roln. - OL PAN [TEKA. Commission of motorization and power industry in agriculture, Polish Academy of Sciences Branch in Lublin], 2009, 9: 93-98.

23. Li L., Li L., Wang Y., Du Y., Q in S. Biorefinery products from the inulin-containing crop Jerusalem artichoke. Biotechnol. Lett., 2013, 35: 471-477 (doi: 10.1007/s10529-012-1104-3).

24. Sa e ngkanuk A., Nuchadomrong S., Jogloy S., Patanothai A., Srijaranai S. A simplified spectrophotometric method for the determination of inulin in Jerusalem artichoke (Helianthus tuberosus L.) tubers. Eur. Food Res. Technol., 2011, 233: 609-616 (doi: 10.1007/s00217-011-1552-3).

25. Kocsis L., Li e b hard P., Praznik W. Einfluss des Erndetermins auf Knollegrosse und Trokensubstanzgehalt sowie Inulin- und Zuckerertrag bei Topinabursorten unterschiedcher Reifzeit (Helianthus tuberosus L.) in semiariden Produktionsgebiet Osterreichs. Pflanzenbauwissenschaften, 2008, 12(1): 8-21.

26. Puttha R., Jogloy S., Wangsomnuk P.P., Srijaranai S., Kesmala T., Patanothai A. Genotypic variability and genotype by environment interactions for inulin content of Jerusalem artichoke germplasm. Euphytica, 2012, 183: 119-131 (doi: 10.1007/s10681011-0520-0).

27. Puangbut D., Jogloy S., Vorasoot N., Srijaranai S., Kesmala T., $\mathrm{Hol}$ b r o o k C.C., P a t a $\mathrm{n}$ o $\mathrm{h}$ a i A. Influence of planting date and temperature on inulin content in Jerusalem artichoke (Helianthus tuberosus L.). Australian Journal of Crop Science, 2012, 6: 1159-1165.

28. Puangbut D., J og loy S., Vorasoot N., P a t a not ha i A. Growth and phenology of Jerusalem artichoke (Helianthus tuberosus L.). Pakistan Journal of Botany, 2015, 47(6): 2207-2214.

29. Puangbut D., Jogloy S., Vorasoot N., Srijaranai S., Holbrook C.C., $\mathrm{P}$ at a n o thai A. Variation of inulin content, inulin yield, and water efficiency for inulin yield 
in Jerusalem artichoke genotypes under different water regimes. Agricultural Water Management, 2015, 152: 142-150 (doi: 10.1016/j.agwat.2015.01.005).

30. Ruttanaprasert R., Jogloy S., Vorasoot N., Kesmala T., Rameshwar S.K. Holbrook C.C., Pat a nothai A. Effect of water stress on total biomass, tuber yield, harvest index and water efficiency in Jerusalem artichoke. Agricultural Water Management, 2016, 166: 130-138 (doi: 10.1016/j.agwat.2015.12.022).

31. Saengthongpinit W., Sajja nantakul T. Influence of harvest time and storage temperature on characteristics of inulin from Jerusalem artichoke (Helianthus tuberosus L.) tubers. Postharvest Biology and Technology, 2005, 37(1): 93-100 (doi: 10.1016/j.postharvbio.2005.03.00).

32. Nazarenko M.N., Barkhatova T.V., Kozhukhova M.A., Burlakova E.V. Izmenenie inulina v klubnyakh topinambura pri khranenii. Nauchnyi zhurnal Kubanskogo GAU, 2013, 94(10). Available http://cyberleninka.ru/article/n/izmenenie-inulina-v-klubnyah-topinamburapri-hranenii. Accessed Octoder 23, 2017 (in Russ.)

33. Barkhatova T.V., Nazarenko M.N., Kozhukhova M.A., Khripko I.A. Obtaining and identification of inulin from Jerusalem artichoke (Helianthus tuberosus L.) tubers. Food and Raw Materials, 2005, 3(2): 13-22.

34. B r e t o n C., S e ri e y s H., B e rvill é A. Gene transfer from wild Helianthus to sunflower: topicalities and limits. Oléagineux, Corp Gras, Lipids, 2010, 13: 104-114 (doi: 10.1051/ocl.2010.0296).

35. Sossey-Alaoui K., S e rieys H., Tersac M., La mbert P., Schilling E., G rive a u Y., K a a n F., Be rvillé A. Evidence for several genomes in Helianthus. Theor. Appl. Genet., 1998, 97: 422-430 (doi: 10.1007/s001220050912).

36. Kays S.J., Kultur F. Genetic variation in Jerusalem artichoke (Helianthus tuberosus L.) flowering date and duration. HortScience, 2005, 40: 1675-1678.

37. Pas'k o N.M. Trudy po prikladnoi botanike, selektsii i genetike, 1974, 53(1): 231-246 (in Russ.)

38. Sh chibrya N.A. V knige: Teoreticheskie osnovy selektsii rastenii. Tom 3 [In: Theoretial basis for plant beeding. V. 3]. Moscow-Leningrad, 1937: 162-175 (in Russ.)

39. Davydovich S.S. Selektsiya i semenovodstvo, 1936, 6: 20-26 (in Russ.)

40. Pas'ko N.M. Nauchnye trudy Maikopskoi opytnoi stantsii VIR, 1973, Vypusk 7: 78-91 (in Russ.)

41. Puttha R., Jogloy S., Suriham B., Wangsomnuk P.P., Kesmala T., Patanothai A. Variations in morphological and agronomic traits among Jerusalem artichoke (Helianthus tuberosus L.) accessions. Genet. Resour. Crop Evol., 2013, 60(2): 731-746 (doi: 10.1007/s10722012-9870-2).

42. Atlagić J., Dozet B., Skorić D. Meiosis and pollen viability in Helianthus tuberosus L. and its hybrids with cultivated sunflower. Plant Breeding, 111: 318-324 (doi: 10.1111/j.14390523.1993.tb00648.x).

43. Janket A., Vorasoot N., Ruttanaprasert R., Kesmala T., Jogloy S. Genotypic variability of yield components and crop maturity in Jerusalem artichoke germplasm. SABRAO Journal of Breeding and Genetics, 2016, 48(4): 474-490.

44. Ruttanaprasert R., Banterng P., Jogloy S., Vorasoot N., Kesmala T., Kanvar R.S., Holbrook C.C., Patanothai A. Genotypic variability for tuber yield, biomass and drought tolerance in Jerusalem artichoke germplasm. Turkish Journal of Agriculture and Forestry, 2014, 38(4): 570-580 (doi: 10.3906/tar-1310-43).

45. Sawichka B., Michalek W. Evaluation and productivity of Helianthus tuberosus L. in the conditions of Central-East Poland. Electronic Journal of Polish Agricultural Universities, 2005, 8(3): \#42. Available http:/www.ejpau.media.pl/volume8/issue3/art-42.html. No date.

46. Rodrigues M.A., Sousa L., Cabanas J.E., Arrobas M. Tuber yield and leaf mineral composition of Jerusalem artichoke (Helianthus tuberosus L.) grown under different cropping practices. Spanish Journal of Agricultural Research, 2007, 5: 545-553.

47. Frese L. Production and utilization of inulin. In: Cultivation and breeding of fructans. M. Suzuki, N.J. Shatterton (eds.). CRC Press, London, 1993: 303-315.

48. Baldini M., Danuso F., Turi M., Vanozzi G.P. Evaluation of new clones of Jerusalem artichoke (Helianthus tuberosus L.) for inulin and sugar yield from stalks and tubers. Ind. Crops Prod., 2004, 19(1): 25-40 (doi: 10.1016/S0926-6690(03)00078-5).

49. Brkjaca J., Bodroza-Solarov M., Krulj J., Mikic A., Jeromela A.M. Quantification of inulin content in selected accessions of Jerusalem artichoke (Helianthus tuberosus L.). Helia, 2014, 37: 105-112 (doi: 10.1515/helia-2014-0009).

50. Seiler G.J., Campbel L.J. Genetic variability for mineral element concentration of wild Jerusalem artichoke forage. Crop Sci., 2004, 44: 289-292 (doi: 10.2135/cropsci2004.2890).

51. Le Page-Digivry M.-T., Barthe P., Garello G. Involvement of endogenous abscisic acid in onset and release of Helianthus annuus embryo dormancy. Plant Physiology, 1990, 92(4): 1164-1168 (doi: 10.1104/pp.92.4.1164).

52. Maiti R.C., Vidyasagar P., Shahapur S.G., Ghosh S.K., Seiler G.J. Development and standardization of a simple technique for breaking seed dormancy in sunflower (Helianthus annuus L.). Helia, 2006, 29(45): 117-126 (doi: 10.2298/HEL0645117M).

53. Sennoi R., Jogloy S., Saksirirat W., Patanothai A. Pathogenicity test of Sclerotium 
rolfsii, a causal agent of Jerusalem artichoke (Helianthus tuberosus L.) stem rot. Asian Journal of Plant Sciences, 2010, 9(5): 281-284 (doi: 10.3923/ajps.2010.281.284).

54. Pas'ko N.M. Byulleten' VIR, 1980, 105: 85-88 (in Russ.)

55. Marchenko I.I. V sbornike: Otdalennaya gibridizatsiya rastenii. Moscow, 1960: 379-395 (in Russ.)

56. Natali L., Giordani T., Polizzi E., Pugliesi C., Fambrini M., Cavallini A. Genomic alterations in the inter-specific hybrid Helianthus annuus $\times$ Helianthus tuberosus. Theoretical and Applied Genetics, 1998, 97: 1240-1247.

57. Davydovich S.S. Selektsiya i semenovodstvo, 1947, 1: 33-37 (in Russ.)

58. Davydovich S.S. Zemlyanaya grusha. Moscow, 1957 (in Russ.)

59. Shchibrya N.A. V knige: Geterozis v rastenievodstve. Stavropol', 1966: 83-101 (in Russ.)

60. Pas'ko N.M. Materialy konferentsii molodykh uchenykh. Adygeisk, 1971, tom 2: 172-177 (in Russ.) 